\title{
CHANGES IN BLOOD LEVELS OF IL1 FAMILY CYTOKINES IN PATIENTS WITH ESSENTIAL HYPERTENSION AFTER HAVING COVID-19
}

Radaeva $\mathrm{OA}^{1} \otimes$, Simbirtsev $\mathrm{AS}^{2}$, Kostina YuA ${ }^{1}$, Iskandyarova MS ${ }^{1}$, Mashnina SV${ }^{1}$, Bessheynov DD, Negodnova EV ${ }^{1}$, Kulyapkin $\mathrm{W}^{1}$

${ }_{1}^{1}$ National Research Mordovia State University, Saransk, Russia

2 State Research Institute of Highly Pure Biopreparations of the Federal Medical Biological Agency, St. Petersburg, Russia

Pathogenetic progression mechanisms in the SARS-CoV-2-essential hypertension (EAH) system are more complex than interaction at the level of angiotensinconverting enzyme 2 (ACE2). The study was aimed to assess the dynamic changes of the IL1 members (IL1 $\beta$, IL1 $\alpha$, IL1ra, IL18, IL18BP, IL37) blood levels in patients with EAH 10, 30, and 180 days after having COVID-19 in order to define cytokine-mediated mechanisms of EAH progression during the period following infection. The study involved four groups of patients: with a history of EAH and COVID-19 (pneumonia/no pneumonia), with a history of COVID-19 (pneumonia/no pneumonia) and no EAH. Cytokine levels were determined by enzyme immunoassay. The study results demonstrate the prolonged proinflammatory immune response during the period following infection in patients with EAH (retaining higher levels of IL $1 \beta$, IL $1 \alpha$, and IL 18 on days 10,30 , and 180 after recovery $(p<0.001$ ) compared to levels measured prior to SARS-CoV-2 infection). In the group with no EAH, the balance of assayed cytokines was restored on day 30 of follow-up. The two-fold increase of blood IL18 levels in patients, having a history of EAH and COVID-19 and showing no increase in the IL18BP levels after 30 days of follow up compared to the values measured prior to infection, is associated with cardiovascular complications occurring during the first six months of follow-up. This makes it possible to hypothesize the importance of these immunoregulatory peptides for the pathogenesis of complications and enhances the relevance of further scientific research.

Keywords: COVID-19, arterial hypertension, IL1 $\beta$, IL $1 \alpha$, IL 18, cardiovascular complications

Author contribution: Radaeva OA — study design, analysis of the results, manuscript editing; Simbirtsev AS - formulating research aim, final version of the article; Kostina YUA — laboratory tests, manuscript editing; Iskandyarova MS — literature analysis, working on the first manuscript draft; Mashnina SV — literature analysis, monitoring of patients; Bessheynov DD — statistical data processing; Negodnova EV — working on the first manuscript draft; Kulyapkin W — statistical processing of data obtained during the $6^{\text {th }}$ month of follow-up.

Compliance with ethical standards: the study was approved by the Ethics Committee of the National Research Mordovia State University (protocol № 12 dated December 14, 2008, protocol № 85 dated May 27, 2020), the research was carried out in accordance with the WMA Declaration of Helsinki (2013) and the protocol of the Convention on Human Rights and Biomedicine (1999) taking into consideration the Additional Protocol to the Convention on Human Rights and Biomedicine, concerning Biomedical Research (2005). Informed consent was submitted by all patients.

$\triangle$ Correspondence should be addressed: Olga A. Radaeva Ulyanova, 26a, Saransk, 430020; radaevamed@mail.ru

Received: 19.05.2021 Accepted: 02.06.2021 Published online: 07.06.2021

DOI: $10.24075 /$ brsmu.2021.026

\section{ИЗМЕНЕНИЕ СОДЕРЖАНИЯ ЦИТОКИНОВ СЕМЕЙСТВА IL1 В КРОВИ БОЛЬНЫХ ЭССЕНЦИАЛЬНОЙ ГИПЕРТЕНЗИЕЙ ПОСЛЕ COVID-19}

О. А. Радаева ${ }^{1}$, А. С. Симбирцев², Ю. А. Костина', М. С. Искандярова', С. В. Машнина'ㄹ, Д. Д. Бесшейнов, Е. В. Негоднова', В. В. Куляпкин

${ }^{1}$ Мордовский государственный университет имени Н. П. Огарева, Саранск, Россия

2 Государственный научно-исследовательский институт особо чистых биопрепаратов Федерального медико-биологического агентства, Санкт-Петербург, Россия

Механизм патогенетического утяжеления в системе SARS-CoV-2-эссенциальной гипертензии (ЭАГ) носит более сложный характер, чем взаимодействие на уровне ангиотензинпревращающего фермента 2 (ACE2). Целью исследования было проанализировать динамику содержания представителей семейства IL 1 (IL1 1 , IL1 $\alpha$, IL1ra, IL18, IL18BP, IL37) в крови больных ЭАГ через 10, 30 и 180 дней после COVID-19 для определения цитокинопосредованных звеньев прогрессирования ЭАГ в постинфекционном периоде. В исследовании участвовали четыре группы пациентов: с ЭАГ и COVID-19 в анамнезе (с пневмонией/без пневмонии), с COVID-19 в анамнезе (с пневмонией/без пневмонии) без ЭАГ. Содержание цитокинов определяли иммуноферментным методом. Полученные результаты демонстрируют пролонгированный характер провоспалительного иммунного ответа в постинфекционном периоде у больных с ЭАГ (сохранение более высоких уровней IL1 $\beta$, IL1 $\alpha$, IL18 на 10-й, 30-й и 180-й дни после выздоровления (p < 0,001) при сопоставлении с периодом до инфицирования SARS-CoV-2). В группе без ЭАГ выявлено восстановление баланса анализируемых цитокинов к 30-му дню наблюдения. Двукратное увеличение содержания IL18 в крови пациентов с ЭАГ и COVID-19 в анамнезе на фоне отсутствия роста IL18BP через 30 дней наблюдения при сравнении с доинфекционным периодом ассоциируется с развитием сердечно-сосудистых осложнений в период с первого по шестой месяц наблюдения, что позволяет выдвинуть гипотезу о значимости данных иммунорегуляторных пептидов в патогенезе осложнений и актуализирует дальнейший научный поиск.

Ключевые слова: COVID-19, артериальная гипертензия, IL1 $\beta$, IL $1 \alpha$, IL 18, сердечно-сосудистые осложнения

Вклад авторов: О. А. Радаева - разработка дизайна исследования, анализ результатов, оформление рукописи; А. С. Симбирцев - формулирование цели исследования, итогового варианта рукописи; Ю. А. Костина - проведение лабораторных исследований, оформление рукописи; М. С. Искандярова работа с литературой, работа над первым вариантом рукописи; С. В. Машнина — работа с литературой, наблюдение за пациентами; Д. Д. Бесшейнов статистическая обработка данных; Е. В. Негоднова - работа над первым вариантом рукописи; В. В. Куляпкин - статистическая обработках данных за 6 месяцев наблюдения.

Соблюдение этических стандартов: исследование одобрено этическим комитетом Мордовского государственного университета имени Н. П. Огарева (протокол № 12 от 14 декабря 2008 г. и протокол № 85 от 27 мая 2020 г.) и проведено в соответствии с требованиями положений Хельсинкской декларации ВМА (2013 г.) и протокола Конвенции Совета Европы о правах человека и биомедицине (1999) с учетом дополнительного протокола к Конвенции по правам человека и биомедицине в области биомедицинских исследований (2005). Все пациенты подписали добровольное информированное согласие.

$\bowtie$ Для корреспонденции: Ольга Александровна Радаева ул. Ульянова, д. 26а, г. Саранск, 430020; radaevamed@mail.ru

Статья получена: 19.05.2021 Статья принята к печати: 02.06.2021 Опубликована онлайн: 07.06.2021

DOI: $10.24075 /$ vrgmu.2021.026 
During the pandemic the efforts of healthcare workers and researchers are more broadly focused on combating the infection with SARS-CoV-2 and the acute mortality reduction. However, there have been increasing reports on the importance of the "long COVID-19" investigation [1]. It is important to consider the delayed effects of SARS-CoV-2 realized through imbalance of cytokine-mediated vectors, underlying the progression of a number of cardiovascular disorders during the period following infection, and the increased risk of complications [2, 3]. The data are discussed, showing links between various types of ARVI and a higher rate of subsequent cardiovascular complications $[4,5]$ : up to four times higher during the first 30 days, and 1.5 times higher over the years, especially in people with arterial hypertension $(\mathrm{AH})$ [6]. The long-term monitoring of patients with SARS-CoV-2 demonstrates the development of cardiovascular complications and metabiomic alterations during the period following infection, however, these data are scarce and require revision in terms of SARS-CoV-2. In addition to the conclusion that individuals with AH may be more susceptible to COVID-19 and are characterized by more severe course of the disease $[7,8]$, the literature also reports that the SARS-CoV-2 infection may trigger both the progression of pre-existing pathological process, and the initiation of different pathological process [3].

Understanding of the relationship between COVID-19 and chronic disorders is important for management of patients with comorbidities during the period following infection. The pathogenetic progression mechanisms in the SARS-CoV-2essential hypertension (EAH) system are more complex than interaction at the level of ACE2. Considering the significance if cytokine-mediated vectors in the EAH pathogenesis, there is a decent chance for alteration of the immune regulation principles associated with hypertension progression after having COVID-19. Immune system is a target for SARS-CoV-2 along with the respiratory system [9], however, currently there is little information on the dynamic changes in the immunoregulatory peptides during the period following the COVID-19 infection. COVID-19 is a novel infectious disease, which explains the scientific community declaration of the importance of acquiring more information about delayed complications in patients with chronic neurological and cardiovascular disorders after SARSCoV-2 infection, as well as about the role of immunoregulatory peptides in the pathogenesis of such complications [10]. The IL1 family members (IL1 $\beta$, IL1 $\alpha$, IL1ra, IL18, IL18BP, and IL37) involved in COVID-19 [2, 11-12] are considered significant factors of endothelial dysfunction progression and vascular remodeling, both due to alteration of the balance within the vasopressor and vasodilator system, and due to reprogramming of matrix metalloproteinases synthesis [13-15].

The study was aimed to assess the dynamic changes of the IL1 member (IL1 $\beta$, IL1 $\alpha$, IL1ra, IL18, IL18BP, IL37) levels in peripheral blood serum of patients with EAH 10, 30, and 180 days after having COVID-19 in order to define the cytokinemediated mechanisms of potential EAH progression during the period following infection.

\section{METHODS}

The assessed data were obtained during phase 3 of the open non-randomized prospective study "Cytokines in Pathogenesis and Diagnosis of EAH" launched in 2008. In the course of the study the four groups of patients were formed, the patients were taken from the database of people with stage $2 \mathrm{EAH}$ (402 people) followed up for 10 (7.5-12.3) years (complex functional, clinical and biochemical examination, which included assessment of levels of 32 cytokines, was performed in 2008 ,
2013, and in January-February 2020): group 1 - patients with stage 2 EAH having a history of COVID-19 without pneumonia; group 2 - patients with stage $2 \mathrm{EAH}$ having a history of SARS CoV-2-associated pneumonia; group 3 - individuals without EAH having a history of COVID-19 without pneumonia; group 4 - individuals without EAH having a history of SARS-CoV-2associated pneumonia (groups 3 and 4 included generally healthy individuals (no hypertension), who were followed up for a long time (154 people) within the framework of the study and were comparable both by age and major clinical and biochemical characteristics). Inclusion criteria: stage 2 $\mathrm{EAH}$; relatively similar antihypertensive therapy prior to SARSCoV-2 infection (ACE inhibitors and/or thiazide diuretics); age 60-65; relatively similar levels of total cholesterol, lipoproteins, triglycerides, glucose prior to SARS-CoV-2 infection; waist circumference less than $102 \mathrm{~cm}$ in men and less than $88 \mathrm{~cm}$ in women, BMl $<25 \mathrm{~kg} / \mathrm{m}^{2}$. Exclusion criteria: history of associated clinical conditions at the start of phase 3 of the study (acute cerebrovascular event, myocardial infarction (MI), angina pectoris, coronary revascularization), kidney failure, type 1 or type 2 diabetes mellitus, autoimmune disorders, allergic diseases, symptomatic arterial hypertension, alcohol or drug addiction, smoking, patient's refusal to participate in the study on a long term basis. The comparison group included generally healthy individuals with systolic blood pressure (SBP) of 100-130 mm Hg and diastolic blood pressure (DBP) of 70-89 $\mathrm{mm} \mathrm{Hg}$.

An essential aspect of the reported study design is the availability of data on the surveyed patients' cytokine status prior to SARS-CoV-2 infection (January-February 2020).

The diagnosis of COVID-19 was established in accordance with the up-to-date interim guidelines for prevention, diagnosis and treatment of the novel coronavirus infection COVID-19 based on the PCR test results (hereinafter PCR test for detection of SARS CoV 2 RNA), as well as the detection of IgM and IgG anti-SARS CoV 2 immunoglobulin level dynamic changes. Two clinical variants were reported in patients: ARVI or pneumonia with no respiratory failure (mild or moderate course). The patients received relatively similar therapy in accordance with the guidelines valid at the time of the therapy (May-October 2020). The fasting blood sanpling was performed at 8 a. m. 10,60 , and 180 days after two negative PCR tests. Blood underwent centrifugation; the separated serum was stored in the labeled tubes at a temperature of $-30^{\circ} \mathrm{C}$ for a period not exceeding 45 days. The levels of IL1 $\beta$, IL $1 \alpha$, IL1ra, IL18, IL18 $\mathrm{BP}$, and IL37 were assessed using enzyme immunoassay in the laboratory of the Department of Immunology, Microbiology, and Virology (Laboratory of Microbiology and Immunology, unlimited license № 13.01.04.0001.Л.000005.06.11) by certified specialists, who used the Personal Lab TM platform for microELISA testing (Adaltis; Italy). The test systems had adequate sensitivity and specificity: IL1 $\beta$ (eBioscience (Bender MedSystems), measurement range - 0.3-250 pg/mL; IL $1 \alpha$ (eBioscience (Bender MedSystems), measurement range 1.06-100.0 pg/mL; IL1ra (eBioscience (Bender MedSystems), measurement range - 30-7,000 pg/mL; IL18 (eBioscience (Bender MedSystems), range — 9-5,000 pg/mL; IL18BP (R\&D Systems, USCN Life Science), range - 0.51-100 ng/mL); IL37 (Fine Biotech), range - 31.2-2,000 pg/mL.

Telephone interviews were conducted monthly in order to detect cardiovascular complications with subsequent verification of information in the medical institution responsible for management of the patient.

Statistical processing of the data was carried out using the Statistica 13.5 software (StatSoft; USA). The data were presented as median $(\mathrm{Me})$ and percentiles $\left(\mathrm{Q}_{0.25}-\mathrm{Q}_{0.75}\right)$. Data 
Table 1. Comparison of serum cytokine levels $(\mathrm{pg} / \mathrm{mL})$ in patients with stage $2 \mathrm{EAH}$ prior to COVID-19 and 10,30 , and 180 days after recovery $\left(\mathrm{Me}\left[\mathrm{Q}_{25}-\mathrm{Q}_{75}\right]\right)$

\begin{tabular}{|c|c|c|c|c|c|c|c|c|}
\hline & \multicolumn{8}{|c|}{ Patients with stage 2 EAH and COVID- 19} \\
\hline & \multicolumn{4}{|c|}{ no pneumonia ( $n=53$ people) } & \multicolumn{4}{|c|}{ pneumonia ( $n=41$ people) } \\
\hline & before COVID-19 & 10 days after & 30 days after & 180 days after & before COVID-19 & 10 days after & 30 days after & 180 days after \\
\hline & 1 & 2 & 3 & 4 & 5 & 6 & 7 & 8 \\
\hline IL1 $\beta$ & $18.7[13.2-22.1]$ & $23.9[20.1-26.4]^{\star 1}$ & $19.6{ }^{\star} 2[13.9-20.8]$ & $25.7[14.8-31]^{\star 1.3}$ & $19.3[14-21.3]$ & $37.8^{\star 2} 2.4[34.3-39.1]$ & $30.2^{* 3.5^{\wedge} 6}[26.7-38.4]$ & $42.3[33.4-47.2]^{\star 4.5 .6 .7}$ \\
\hline IL1 $\alpha$ & $13.2[10.6-15.5]$ & $16.9[12.6-19.1]^{\star 1}$ & $14.4[11-16.6]^{\star 1.2}$ & $18.3[13-23.4]^{\star 1.2 .3}$ & $20.7[13.1-22.7]^{\star 1}$ & $26.7[18.1-31.8]^{\star 2.5}$ & $31.1[25.7-33.4]^{\times 3.5 .6}$ & $35.6[29.3-38.1]^{\star 4.5 .6 .7}$ \\
\hline IL1ra & 698 [602-754] & $750[665-812]^{\wedge 1}$ & $690[508-787]^{\star 2}$ & $984[733-1187]^{\star 1.2 .3}$ & $612[524-690]^{11}$ & $645[572-735]^{\star 2}$ & $602[518-720]^{* 3}$ & $621[503-668]^{\star 4}$ \\
\hline IL18 & 301 [243-352] & $399[243-420]^{\wedge 1}$ & $411[270-452]^{\star 1}$ & $412[264-436]^{\star 1}$ & $394[321-658]^{\wedge 1}$ & $460[345-732]^{\wedge 2.5}$ & $479[345-532]^{\star 3.5}$ & $474[387-609]^{*} 1^{\wedge 4.5}$ \\
\hline IL18 BP & 5980 [5311-6720] & $7900^{* 1}[7132-8640]$ & $8190 * 1[7243-8930]$ & $7870 * 1[5311-6720]$ & $5110^{\star 1}[4963-6265]$ & $4960 * 2[4872-6120]$ & $5230^{* 3}[4850-6334]$ & $4890^{* 4}[4730-5970]$ \\
\hline IL37 & $65.7[54.7-68.9]$ & $68.3[51.2-72.4]$ & $64.9[57.2-75.1]$ & $88.3[76.4-94.4]^{\star 1.2 .3}$ & $52.7[48.1-60.3]^{\star 1}$ & $51.3[44.2-55.1]^{\star 2}$ & $52.1[46.3-56.7]^{\star 3}$ & $49.7[45.4-55.3]^{\star 4}$ \\
\hline
\end{tabular}

Note: * - significance level $p<0.001, \wedge-p<0.01,{ }^{\wedge}-p<0.05$ (the Wilcoxon test was used for related samples, and the Mann-Whitney $U$-Test was used for independent samples)

distribution was different from the Gauss-Laplace distribution, therefore, the Wilcoxon test was used for comparison of dependent samples, and the Mann-Whitney $U$-Test was used for comparison of independent samples.

\section{RESULTS}

Prior to SARS-CoV-2 infection, the patients with stage $2 \mathrm{EAH}$ were characterized by higher IL1 $\beta, I L 1 \alpha, I L 18, I L 18 B P$, and IL37 levels in peripheral blood serum compared to generally healthy individuals $(p<0.001)$ (Tables 1 and 2). After having COVID-19, the different quantitative and qualitative indicators, reflecting dynamic changes of blood IL1 $\beta, I L 1 \alpha, I L 1$ ra, IL18, IL18BP, and IL37 levels, were measured in patients with stage 2 EAH compared to patients who had been infected with SARSCoV-2 but had no EAH. Thus, in individuals with stage $2 \mathrm{EAH}$, regardless of the COVID-19 form (pneumonia/no pneumonia), higher levels of proinflammatory IL1 family members (IL1 $\beta$, $\mathrm{IL} 1 \alpha$ ) were observed 10 days after the second negative PCR test compared to the period prior to infection $(p<0.001$; see Table 1). Among patients with no hypertension, this pattern was limited to individuals with SARS-CoV-2-associated pneumonia. Furthermore, blood levels of IL1 $\beta, I L 1 \alpha$ in this category of patients were back to normal (the levels measured prior to infection were achieved) on day 30 after recovery and remained the same after 6 months (see Table 2). Among patients with $\mathrm{EAH}$, the decrease in $\mathrm{IL} 1 \beta$ and $\mathrm{IL} 1 \alpha$ levels compared to data obtained on day 10 after recovery was also observed, however, the levels measured prior to infection were not achieved in the group of patients having a history of EAH and SARS-CoV-2associated pneumonia. It is important to note the repeated increase in blood levels of IL1 $\beta$ and IL1 $\alpha$ in patients with EAH (regardless of the history of pneumonia) 180 days after negative PCR test compared to levels measured prior to infection and on day 30 after laboratory-confirmed recovery (negative PCR test; see Table 1). When assessing the individual indicators, it was discovered that the trend of IL $1 \alpha$ level increase by the end of month 6 resulted primarily from the level increase in the group of female patients with EAH (in women the level increased by $79 \%(75 \% \mathrm{Cl}[61-87])$ compared to data obtained after a month, and in male patients it increased by $32 \%$ (75\% Cl [12-44]) respectively; $p<0.001$ ). No sex-related dynamic changes in IL1 $\beta$ levels were observed. Meanwhile, the increase in the $\mathrm{IL} 1 \beta$ and IL $1 \alpha$ levels during the period following infection in the group of patients with EAH and COVID-19 without pneumonia came against the backdrop of elevated anti-inflammatory IL1ra level, which matched trends observed in the group of patients with no hypertension. Patients with EAH and COVID-19 with pneumonia were characterized by the increase in levels of $I L 1 \beta$ and IL $1 \alpha$ and no increase in blood levels of the natural antagonist IL1ra (see Table 1).

Analysis of dynamic changes in the levels of IL18 and IL18 $\mathrm{BP}$ showed that the patients with stage $2 \mathrm{EAH}$, regardless of COVID-19 disease form (pneumonia/no pneumonia), had elevated serum IL18 levels 10 days after negative PCR test compared to levels measured prior to infection $(p<0.001)$; this pattern remained the same 30 and 180 days after (see Table 1). It is important to note that in the group of patients with $\mathrm{EAH}$ and no history of pneumonia, the increase in the levels of IL18 was accompanied by an increase in the levels of IL18 BP $(p<0.001)$, which remained the same both 30 and 180 days after the laboratory-confirmed recovery; no compensatory increase in the levels of IL18 BP during the period following infection was observed in the group of patients having a history of $\mathrm{EAH}$ and pneumonia $(p<0.05)$. It was also determined that individuals with stage $2 \mathrm{EAH}$ and the history of COVID-19 without pneumonia had significantly higher levels of IL37 180 days after the negative PCR test compared both to the levels

Table 2. Comparison of serum cytokine levels $(\mathrm{pg} / \mathrm{mL})$ in patients with no stage $2 \mathrm{EAH}$ prior to COVID-19 and 10, 30 , and 180 days after recovery $\left(\mathrm{Me}\left[\mathrm{Q}_{25}-\mathrm{Q}_{75}\right]\right)$

\begin{tabular}{|c|c|c|c|c|c|c|c|c|}
\hline & \multicolumn{8}{|c|}{ COVID-19 patients with no EAH } \\
\hline & \multicolumn{4}{|c|}{ no pneumonia ( $n=41$ people) } & \multicolumn{4}{|c|}{ pneumonia ( $n=44$ people) } \\
\hline & before COVID-19 & 10 days after & 30 days after & 180 days after & before COVID-19 & 10 days after & 30 days after & 180 days after \\
\hline & 1 & 2 & 3 & 4 & 5 & 6 & 7 & 8 \\
\hline IL1 $1 \beta$ & $5.12[4.83-5.32]$ & $5.33[4.12-5.2]$ & $5.29[8.89-5.41]$ & $4.97[3.65-5.44]$ & $5.38[4.97-5.44]$ & $17.2[14.1-20.1]^{\star 2.4}$ & $5.72[3.3-4.15]^{* 6}$ & $5.42[4.53-5.65]^{\star 4.6}$ \\
\hline IL $1 \alpha$ & $3.22[3.04-3.41]$ & $3.39[3.16-3.56]$ & $2.99[2.56-3.45]$ & 3.18 [2.93-3.39] & $3.14[2.97-3.24]$ & $4.72[3.11-5.82]^{\star 2.5}$ & $3.25^{\star 6}[2.61-2.49]$ & $3.18[2.67-4.14]^{* 6}$ \\
\hline IL1ra & 697 [584-791] & $830[690-914]^{*} 1$ & $667[458-733]^{\star 1.2}$ & $728[602-816]^{\star 2}$ & 657 [504-731] & $843[693-913]^{* 2}$ & $609[515-769]^{* 6}$ & $642[526-712]^{\wedge 4^{*} 6}$ \\
\hline IL18 & $162[145-197]$ & 157 [137-172] & 166 [151-183] & 147 [139-203] & $234[177-267]^{\wedge 1}$ & $298[235-367]^{\star 2 \wedge 5}$ & $247[224-274]^{\star 3.6}$ & $228[207-259]^{\star 1.4 .6}$ \\
\hline IL18 BP & $4880[3510-5670]$ & $5070[3670-5830]$ & $4834[3220-5470]$ & $4993[3440-5580]$ & $4768[3640-5721]$ & $5930^{* 2.5}[4930-8216]$ & $6200^{* 3}[4850-7334]$ & $6180^{\star 4.5}[4603-7100]$ \\
\hline IL37 & 80 [68.7-93.3] & 76 [62.3-89.4] & $78.9[67.4-86.6]$ & $82.3[61.2-94.6]$ & $77.1[63.3-95.7]$ & $74.4[66.2-83.7]$ & $75.3[65.7-82.3]$ & $79.5[55.7-85.3]$ \\
\hline
\end{tabular}

Note: * - significance level $p<0.001, \wedge-p<0.01,{ }^{\wedge}-p<0.05$ (the Wilcoxon test was used for related samples, and the Mann-Whitney $U$-Test was used for independent samples) 
measured during the period prior to infection $(p<0.001)$ and the indicators measured in patients with stage $2 \mathrm{EAH}$ and a history of COVID-19 with pneumonia $(p<0.001)$. When comparing periods prior to infection and following infection, no changes in the levels of IL18, IL18 BP, and IL37 were detected in patients with EAH, who had had COVID-19 not involving lungs $(p<0.05)$. In the group of patients with SARS-CoV-2associated pneumonia having no pneumonia, the levels of IL18 and IL18 BP increased compared to levels measured prior to SARS-CoV-2 infection $(p<0.001)$. However, the levels of those were back to the values measured prior to infection 30 days later (see Table 2). No dynamic changes in the IL37 levels were detected in patients having no EAH during the period following infection $(p<0.05)$.

Comparison of cytokine levels measured prior to infection in patients with SARS-CoV-2-associated pneumonia and stage $2 \mathrm{EAH}$, and patients with EAH and no pneumonia showed that the patients with $\mathrm{EAH}$ and pneumonia demonstrated greater increase in the peripheral blood serum levels of IL $1 \alpha$ and IL18 $(p<0.001)$ together with lower concentrations of IL1ra, IL18 $\mathrm{BP}$, and IL37 $(p<0.001)$ compared with the patients with EAH and COVID-19 without pneumonia. No such pattern was observed in the group with no EAH.

It is important to mention, that comparison with classical scales for calculation of cardiovascular complication risk in patients with $\mathrm{AH}$ showed the following: the patients were comparable both prior to COVID-19 and after COVID-19, however, acute coronary syndrome, acute stroke and transient ischemic attack occurred in eight patients (males) with EAH and COVID-19 (pneumonia) during 1-6 months of follow-up. Considering the limited number of individuals with complications during the period following infection, their data were assessed separately: the patients were characterized by two-fold increase in peripheral blood serum levels of IL18 after 30 days of follow-up compared to levels measured prior to infection, as well as the increase by $50 \%$ compared to values measured on day 10 (prior to infection - 410 [397-426] pg/mL; day 10 562 [544-681] pg/mL; day 30 - 824 [807-903] pg/mL). In the group of patients with EAH and a history of SARS-CoV-2associated pneumonia having no cardiovascular complications in the next months (days 30-180 of follow-up), there were no dynamic changes in the IL18 levels on day 30 compared to day 10 of follow-up. The IL18 level increase in cases of subsequent complications was associated with individual low blood levels of IL18BP (prior to infection - 4,805 [4,793-4,826] pg/mL; day $10-4,786[4,741-4,798] \mathrm{pg} / \mathrm{mL} ;$ day $30-4,630[4,665-$ 4,662] pg/mL); and IL37 (prior to infection - 46.9 [46.7-47.3] $\mathrm{pg} / \mathrm{mL}$; day $10-44.5$ [44.1-44.9] pg/mL; day $30-45.1$ [44.6-45.5] $\mathrm{pg} / \mathrm{mL}$ ). This corresponded to the first quartile when analyzing the patients' distribution taking into account the levels of IL18BP and IL37 measured both prior to infection and later. Comparison with patients having no complications during the first six months revealed no differences in the levels of other IL1 family members. Two men in the group with a history of EAH and COVID-19 (no pneumonia) also had acute stroke after the laboratory-confirmed recovery (during 1-6 months of follow-up) and had similar features of the IL1 system, as well as individual qualitative and quantitative characteristics, different from that of individuals having a history of EAH and COVID-19 (no pneumonia).

\section{DISCUSSION}

The evidence of dynamic changes in the levels of proinflammatory IL 1 family members (IL $1 \beta, I L 1 \alpha$, and IL 18) and their natural antagonists (IL1ra, IL18BP) in patients, who had had COVID-19, was obtained during the study. These data confirmed the prolonged proinflammatory immune response during the period following infection in patients with EAH (changes from the levels measured prior to infection persisted for 6 months after laboratory-confirmed recovery) compared to generally healthy individuals (cytokine levels reached the values measured prior to infection 30 days after the laboratoryconfirmed recovery in individuals with SARS-CoV-2-associated pneumonia, and 10 days after recovery in patients with no pneumonia). Other researchers also noted the significance of changes in the levels of a number of immunoregulatory peptides (IL6, MCP1, IP10, etc.) in COVID-19 patients [16], specifying the proinflammatory activity and the relationship with potential progression of concomitant diseases in the future. These data are scarce due to the novelty of the virus; there is no information about the patterns considering the cytokine levels in COVID-19 patients measured prior to infection. This increases the relevance of the reported study aimed at assessment of the changes in blood levels of IL1 $\beta$, IL1 $\alpha$, IL1ra, IL18, IL18 BP, IL37 taking into account the period prior to SARS-CoV-2 infection. A long-lasting retention of the elevated proinflammatory IL $1 \beta$, IL $1 \alpha$ and IL18 concentrations in the blood of post-COVID patients is essential for "enhancement" of the hypertension progression pathogenetic aspects. The evidence of the IL1 $\beta$ stimulatory effect on the ADMA levels (mediated vasopressor due to protein arginine methyltransferase (PRMT) activation and inhibition of dimethylarginine dimethylaminohydrolase (DDAH) has been pubished $[17,18]$. Moreover, the IL $1 \alpha-N F-\kappa B-C C L 2$ signaling pathway has been described, promoting the immune cell migration and consolidation of vascular remodeling [19], which has been also confirmed by our data [13] supporting greater significance in women with $\mathrm{EAH}$. It should be noted that in patients with a history of EAH and SARS-CoV-2-associated pneumonia, the increase in the levels of IL $1 \beta$ and IL $1 \alpha, \mathrm{IL} 18$ is not accompanied by the compensatory increase in the levels of natural antagonists (IL1ra and IL18BP, IL3). According to the data published so far, the IL37 and IL18BP functional complex formation is due to common receptor subunits of IL37 and IL18ra, it is directed both at leveling of the IL18 vasopressor effect, and at direct blocking of the SDMA synthesis [20, 21]. No increase in their levels in patients with EAH after SARSCoV-2 infection together with the elevated IL18 levels increase the likelihood of vasopressor and remodeling effects realization in the IL18-IL18BP-IL37 system with a potentially higher risk of target organ (myocardium, brain, etc.) damage in patients with $\mathrm{EAH}$. This hypothesis is partially confirmed by analysis of individual curves for cytokine level changes in the peripheral blood serum of patients with acute coronary syndrome, acute stroke and transient ischemic attack, characterized by twofold increase in blood IL18 levels without any compensatory increase in the levels of IL18BP and IL37 during the first month of follow-up. The significantly increased IL18 levels in patients with EAH during the period following the COVID infection can be a key element of the pathogenetic chain, which mediates vascular remodeling promoted by AT II [22], with secondary left ventricular dysfunction progression and increased intimamedia thickness of the common carotid artery, which is a consequence of $\mathrm{AH}$ and a marker of future cardiovascular risk in patients [23]. The increased IL18 synthesis during the period following the COVID infection may be also due to activation of CD147, the potential receptor for SARS-CoV-2 adhesion [24], which induces the IL18 mRNA via stimulation of binding sites in the NF-KB and AP1 (activator protein 1) for the IL18 gene promoter through Rac1-mediated PI3K/Akt/ 
IKK (phosphatidylinositol 3-kinase/Akt//kB kinase)-dependent

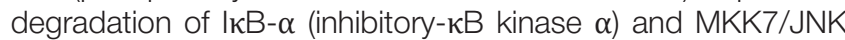
(mitogen-activated proteinkinase kinase 7/c-Jun N-terminal kinase)-coupled AP1 activation [25], which is of greater pathophysiological significance in people with high IL18 levels/ low IL18BP-IL37 levels prior to COVID infection and has been revealed during our study.

It is important to mention that patients with SARS-CoV2associated pneumonia had higher levels of IL1 $\alpha$ and IL18 in peripheral blood serum prior to infection amidst lower levels of antagonists (IL1ra, IL18BP and IL37) compared to patients with $\mathrm{EAH}$ and COVID-19 without pneumonia. This suggests the importance of the reported cytokine concentrations and ratio (cytokine status of the patient prior to infection) upon SARS-CoV-2 entry for initiation of pathological process in the lung tissue. However, no differences related to presence of pneumonia were revealed in patients with no EAH and low levels of IL $1 \alpha$ and IL18 prior to infection. Therefore, one could speak of potential IL1 $\alpha$ - and IL18-mediated elements of pneumonia pathogenesis in patients with COVID-19 and EAH, as well as of dose-dependent effects of the reported cytokines in this category of patients.

\section{References}

1. Mitrani RD, Dabas N, Goldberger JJ. COVID-19 cardiac injury: Implications for long-term surveillance and outcomes in survivors. Heart Rhythm. 2020; 17 (11): 1984-90.

2. Huang C, Wang Y, Li X, Ren L, Zhao J, Hu Y, et al. Clinical features of patients infected with 2019 novel coronavirus in Wuhan, China. Lancet. 2020; 395 (10223): 497-506.

3. Alyammahi SK, Abdin SM, Alhamad DW, Elgendy SM, Altell AT Omar HA. The dynamic association between COVID-19 and chronic disorders: An updated insight into prevalence, mechanisms and therapeutic modalities. Infect Genet Evol. [Internet] 2021 [cited 2021 Mach 8]; 87: [about 1 p.]. Available from: https://www.sciencedirect.com/science/article/pii/ S1567134820304780?via\%3Dihub.

4. Nguyen JL, Yang W, Ito K, Matte TD, Shaman J, Kinney PL. Seasonal influenza infections and cardiovascular disease mortality. JAMA Cardiol. 2016; 1 (3): 274-81.

5. Brack MC, Lienau J, Kuebler WM, Witzenrath M. Cardiovascular sequelae of pneumonia. Curr Opin Pulm Med. 2019; 25 (3): 257-62.

6. Corrales-Medina VF, Alvarez KN, Weissfeld LA, Angus DC Chirinos JA, Chang CC, et al. Association between hospitalization for pneumonia and subsequent risk of cardiovascular disease. JAMA. 2015; 313 (3): 264-74.

7. Richardson S, Hirsch JS, Narasimhan M. Presenting characteristics, comorbidities, and outcomes among 5700 patients hospitalized with COVID-19 in the New York City area. JAMA. 2020; 323 (20): 2052-9.

8. Korostovceva LS, Rotar OP, Konradi AO. Covid-19: kakovy riski pacientov S arterial'noj gipertenziej? AG. 2020; 26 (2): 124-32. Russian.

9. Liu Y, Zhang HG. Vigilance on New-Onset Atherosclerosis Following SARS-CoV-2 Infection. Front Med (Lausanne). [Internet] 2021 Jan [cited 2021 Apr 24] 20; 7: [about 1 p.]. Available from: https://jamanetwork.com/journals/jama/fullarticle/2091304

10. Carod-Artal FJ. Neurological complications of coronavirus and COVID-19. Complicaciones neurológicas por coronavirus y COVID-19. Rev Neurol. 2020; 70 (9): 311-22.

11. Van de Veerdonk FL, Netea MG. Blocking IL1 to prevent respiratory failure in COVID-19. Crit Care. [Internet] 2020 Jul 18 [cited 2021 Apr 24]; 24 (1): [about 1 p.]. Available from: https://ccforum. biomedcentral.com/articles/10.1186/s13054-020-03166-0.

12. Rowaiye AB, Okpalefe OA, Onuh Adejoke O, Ogidigo JO, Hannah Oladipo O, Ogu AC. Attenuating the Effects of Novel COVID-19

\section{CONCLUSION}

The study results confirm the scientific importance of studying the dynamic changes in blood levels of IL1 family members in patients having a history of EAH and SARS-CoV-2 infection for construction of individual immunopathogenetic schemes of hypertension progression. The data obtained increase the relevance of the further monitoring used to confirm the hypothesis on the IL18-IL18BP role in the immunopathogenesis of delayed cardiovascular complications in patients having a history of EAH and COVID-19. It is necessary to perform the further comparison of quantitative characteristics of a wide range of cytokines, vasoactive substances, and functional indicators, as well as to carry out multivariate correlation analysis and selection of potential independent criteria with high sensitivity and specificity for the risk of cardiovascular complications in order to confirm the hypothesis that cytokines may be considered the predictive markers in this clinical situation. Understanding of the delayed cardiovascular complication cytokine-mediated mechanisms may change therapeutic approach (therapeutic strategy) to management of patients during both the acute COVID-19 period and the period following infection.
(SARS-CoV-2) Infection-Induced Cytokine Storm and the Implications. J Inflamm Res. 2021; 14: 1487-510.

13. Radaeva OA. Citokiny v patogeneze i diagnostike jessencial'noj arterial'noj gipertenzii [dissertacija]. M., 2019. Russian.

14. Krishnan SM, Ling YH, Huuskes BM, Ferens DM, Saini N, Chan CT. Pharmacological inhibition of the NLRP3 inflammasome reduces blood pressure, renal damage, and dysfunction in salt-sensitive hypertension. Cardiovasc Res. 2019; 115 (4): 776-87.

15. Savoia C, Volpe M, Kreutz R. Hypertension, a Moving Target in COVID-19: Current Views and Perspectives. Circ Res. 2021; 128 (7): 1062-79.

16. Siripanthong B, Nazarian S, Muser D. Recognizing COVID-19related myocarditis: The possible pathophysiology and proposed guideline for diagnosis and management. Heart Rhythm. 2020; 17 (9): 1463-71.

17. McMaster WG, Kirabo A, Madhur MS, Harrison DG. Inflammation, immunity, and hypertensive end-organ damage. Circ Res. 2015; 116 (6): 1022-33

18. Tain Y-L, Hsu C-N. Toxic Dimethylarginines: Asymmetric Dimethylarginine (ADMA) and Symmetric Dimethylarginine (SDMA). Toxins. 2017; 9 (3): 92-97.

19. Paish HL, Kalson NS, Smith GR, et al. Fibroblasts Promote Inflammation and Pain via $\mathrm{IL} 1 \alpha$ Induction of the Monocyte Chemoattractant Chemokine (C-C Motif) Ligand 2. Am J Pathol. 2018; 188 (3): 696-714.

20. Conti P, Lessiani G, Kritas SK, Ronconi G, Caraffa A, Theoharides TC Mast cells emerge as mediators of atherosclerosis: Special emphasis on IL37 inhibition. Tissue \& Cell. 2017; 49 (3): 393-400.

21. Radaeva OA, Simbircev AS. Analiz patogeneticheskih svjazej IL18, IL18BP, IL37 i vazoaktivnyh veshhestv (AT II, ET-1, NO, ADMA, SDMA, ENOS, INOS, NT-PROCNP i NT-PROBNP) pri jessencial'noj arterial'noj gipertenzii. Medicinskij vestnik Severnogo Kavkaza. 2019; 14 (1-2): 235-8.

22. Valente AJ, Yoshida T, Murthy SN, Sakamuri SS, Katsuyama M, Clark RA, et al. Angiotensin II enhances AT1-Nox1 binding and stimulates arterial smooth muscle cell migration and proliferation through AT1, Nox1, and interleukin-18. Am J Physiol Heart Circ Physiol. 2012; 303 (3): 282-96.

23. OZzbiçer S, Ulucam ZM. Association between Interleukin-18 Level and Left Ventricular Mass Index in Hypertensive Patients. Korean Circulation Journal. 2017: 47 (2): 238-44.

24. Wang K, Chen W, Zhang Z, Deng Y, Lian JQ, Du P, et al. CD147- 
spike protein is a novel route for SARS-CoV-2 infection to host cells. Signal Transduct Target Ther. [Internet] 2020 Dec 4 [cited 2021 Apr 24]; 5 (1): [about 1 p.]. Available from: https://www. nature.com/articles/s41392-020-00426-x.

25. Venkatesan B, Valente AJ, Prabhu SD, Shanmugam P, Delafontaine P,
Chandrasekar B. EMMPRIN activates multiple transcription factors in cardiomyocytes, and induces interleukin-18 expression via Rac1-dependent PI3K/Akt/IKK/NF-kB and MKK7/JNK/AP-1 signaling. Journal of Molecular and Cellular Cardiology. 2010; 49 (4): 655-63.

\section{Литература}

1. Mitrani RD, Dabas N, Goldberger JJ. COVID-19 cardiac injury: Implications for long-term surveillance and outcomes in survivors. Heart Rhythm. 2020; 17 (11): 1984-90.

2. Huang C, Wang Y, Li X, Ren L, Zhao J, Hu Y, et al. Clinical features of patients infected with 2019 novel coronavirus in Wuhan, China. Lancet. 2020; 395 (10223): 497-506.

3. Alyammahi SK, Abdin SM, Alhamad DW, Elgendy SM, Altell AT, Omar HA. The dynamic association between COVID-19 and chronic disorders: An updated insight into prevalence, mechanisms and therapeutic modalities. Infect Genet Evol. [Internet] 2021 [cited 2021 Mach 8]; 87: [about 1 p.]. Available from: https://www.sciencedirect.com/science/article/pii/ S1567134820304780?via\%3Dihub.

4. Nguyen JL, Yang W, Ito K, Matte TD, Shaman J, Kinney PL. Seasonal influenza infections and cardiovascular disease mortality. JAMA Cardiol. 2016; 1 (3): 274-81.

5. Brack MC, Lienau J, Kuebler WM, Witzenrath M. Cardiovascular sequelae of pneumonia. Curr Opin Pulm Med. 2019; 25 (3): 257-62.

6. Corrales-Medina VF, Alvarez KN, Weissfeld LA, Angus DC, Chirinos JA, Chang CC, et al. Association between hospitalization for pneumonia and subsequent risk of cardiovascular disease. JAMA. 2015; 313 (3): 264-74.

7. Richardson S, Hirsch JS, Narasimhan M. Presenting characteristics, comorbidities, and outcomes among 5700 patients hospitalized with COVID-19 in the New York City area. JAMA. 2020; 323 (20): 2052-9.

8. Коростовцева Л. С., Ротарь О. П., Конради А. О. Covid-19: каковы риски пациентов с артериальной гипертензией? АГ 2020; 26 (2): 124-32.

9. Liu Y, Zhang HG. Vigilance on New-Onset Atherosclerosis Following SARS-CoV-2 Infection. Front Med (Lausanne). [Internet] 2021 Jan [cited 2021 Apr 24] 20; 7: [about 1 p.]. Available from: https://jamanetwork.com/journals/jama/fullarticle/2091304.

10. Carod-Artal FJ. Neurological complications of coronavirus and COVID-19. Complicaciones neurológicas por coronavirus y COVID-19. Rev Neurol. 2020; 70 (9): 311-22.

11. Van de Veerdonk FL, Netea MG. Blocking IL1 to prevent respiratory failure in COVID-19. Crit Care. [Internet] 2020 Jul 18 [cited 2021 Apr 24]; 24 (1): [about 1 p.]. Available from: https://ccforum. biomedcentral.com/articles/10.1186/s13054-020-03166-0.

12. Rowaiye AB, Okpalefe OA, Onuh Adejoke O, Ogidigo JO, Hannah Oladipo O, Ogu AC. Attenuating the Effects of Novel COVID-19 (SARS-CoV-2) Infection-Induced Cytokine Storm and the Implications. J Inflamm Res. 2021; 14: 1487-510.

13. Радаева О. А. Цитокины в патогенезе и диагностике эссенциальной артериальной гипертензии [диссертация]. М., 2019.
14. Krishnan SM, Ling YH, Huuskes BM, Ferens DM, Saini N, Chan CT. Pharmacological inhibition of the NLRP3 inflammasome reduces blood pressure, renal damage, and dysfunction in salt-sensitive hypertension. Cardiovasc Res. 2019; 115 (4): 776-87.

15. Savoia C, Volpe M, Kreutz R. Hypertension, a Moving Target in COVID-19: Current Views and Perspectives. Circ Res. 2021; 128 (7): 1062-79.

16. Siripanthong B, Nazarian S, Muser D. Recognizing COVID-19related myocarditis: The possible pathophysiology and proposed guideline for diagnosis and management. Heart Rhythm. 2020; 17 (9): 1463-71.

17. McMaster WG, Kirabo A, Madhur MS, Harrison DG. Inflammation, immunity, and hypertensive end-organ damage. Circ Res. 2015; 116 (6): 1022-33.

18. Tain Y-L, Hsu C-N. Toxic Dimethylarginines: Asymmetric Dimethylarginine (ADMA) and Symmetric Dimethylarginine (SDMA). Toxins. 2017; 9 (3): 92-97.

19. Paish HL, Kalson NS, Smith GR, et al. Fibroblasts Promote Inflammation and Pain via $\mathrm{IL} 1 \alpha$ Induction of the Monocyte Chemoattractant Chemokine (C-C Motif) Ligand 2. Am J Pathol. 2018; 188 (3): 696-714.

20. Conti P, Lessiani G, Kritas SK, Ronconi G, Caraffa A, Theoharides TC. Mast cells emerge as mediators of atherosclerosis: Special emphasis on IL37 inhibition. Tissue \& Cell. 2017; 49 (3): 393-400.

21. Радаева О. А., Симбирцев А. С. Анализ патогенетических связей IL18, IL18BP, IL37 и вазоактивных веществ (AT II, ET-1, NO, ADMA, SDMA, ENOS, INOS, NT-PROCNP и NT-PROBNP) при эссенциальной артериальной гипертензии. Медицинский вестник Северного Кавказа. 2019; 14 (1-2): 235-8.

22. Valente AJ, Yoshida T, Murthy SN, Sakamuri SS, Katsuyama M, Clark RA, et al. Angiotensin II enhances AT1-Nox1 binding and stimulates arterial smooth muscle cell migration and proliferation through AT1, Nox1, and interleukin-18. Am J Physiol Heart Circ Physiol. 2012; 303 (3): 282-96.

23. OZzbiçer S, Ulucam ZM. Association between Interleukin-18 Level and Left Ventricular Mass Index in Hypertensive Patients. Korean Circulation Journal. 2017; 47 (2): 238-44.

24. Wang $\mathrm{K}$, Chen W, Zhang Z, Deng Y, Lian JQ, Du P, et al. CD147spike protein is a novel route for SARS-CoV-2 infection to host cells. Signal Transduct Target Ther. [Internet] 2020 Dec 4 [cited 2021 Apr 24]; 5 (1): [about 1 p.]. Available from: https://www. nature.com/articles/s41392-020-00426-x.

25. Venkatesan B, Valente AJ, Prabhu SD, Shanmugam P, Delafontaine P, Chandrasekar B. EMMPRIN activates multiple transcription factors in cardiomyocytes, and induces interleukin-18 expression via Rac1dependent PI3K/AKt/IKK/NF-KB and MKKT/JNK/AP-1 signaling. Journal of Molecular and Cellular Cardiology. 2010; 49 (4): 655-63. 